\title{
ALIRAN PEMIKIRAN EKONOMI ISLAM KONTEMPORER
}

\section{Oleh:}

\author{
Nurul Wahida Aprilya (90100118110) \\ Fakultas Ekonomi dan Bisnis Islam UIN Alauddin Makassar \\ e-mail:wahidaprilya@gmail.com
}

Secara umum, ekonomi merupakan perilaku manusia yang berhubungan dengan bagaimana proses dan cara memperoleh dan mendayagunakan produksi, distribusi, dan konsumsi. Ekonomi Islam adalah bagian integaral dari ajaran agama Islam, yang meyakini adanya sang pencipta bahwa ia telah menciptakan alam semesta manusia dan kehidupan, dimana tuhan tidak hanya menciptakan begitu saja tetapi tuhan menyertakan guidance kitab pedoman, petunjuk kehidupan yaitu Al-Qur'an dan al-Sunnah demi menjamin terciptanya keselarasan hidup dan keharmonisan sosial umat manusia (Sirajuddin \& Tamsir, 2019:215). Pemikiran ekonomi islam muncul bersamaan dengan diturunkannya Al-Qur'an dan masa kehidupan Rasulullah pada akhir abad 6 M hingga awal abad 7 M (Janwari, 2016:8). Perkembangan pemikiran ekonomi islam pada dasarnya sudha dibahas dan dipraktikkan dalam kehidupan sehari-hari. Bahkan sejak masa Rasulullah SAW dan sahabt-sahabatnya. Akan tetapi, perkembangan ekonomi islam terhenti, karena adanya dikatomi antara agama dan ilmu pengetahuan yang lahir akibat dogmatisasi yang terjadi pada masa kegelapan. Selain itu kuatnya dominasi ekonomi kapitalis dan sosiolis buah dari politik imperiaslisme dan kolonialisme menjadikan ekonomi islam makin tergerurus dan mulai ditinggalkan. Kemudian diperparah dengan diabaikannya kontribusi pemekiran ekonomi oleh para ilmuan barat (Havis Aravik, 2017:8).

Pada tahun 1930, barulah ekonomi islam kembali bergeliat menancapkan eksistensinya sebagai salah satu bangunan ilmu yang kukuh dan mampu menjawab berbagai permasalahan-permasalahan ekonomi kontemporer. Dalam kontek wacana 
pemikiran ekonomi islam kontemporer, maka akan di dapatkan tiga mazhab yang sangat mempengaruhi teori-teori ekonomi islam (Havis Aravik, 2017:5), yaitu:

1. Mazhab Iqtishaduna

Mazhab ini dipelopori oleh Muhammad Baqir al-Sadr dengan bukunya Iqtishaduna. Baqir as-Sadr dilahirkan di Kadhimiyeh, Baghad. Pada 1 Maret 1935. Pola utama dalam pemikiran ini adalah tentang permecahan masalah ekonomi yang muncul karena adanya distribusi yang tidak merata dan adil sebagai pengaruh dari ekonomi kapitalis yang menguntungkan pihak yang kuat dan kaya. Menurut Baqir al-Sadr, terdapat perbedaan antara ilmu ekonomi dengan islam. Hal ini dilatarbelakangi atas ketidaksetujuannya terhadap definisi dari ilmu ekonomi yang menanggap bahwa masalah ekonomi muncul akibat sumber daya ekonomi yang terbatas sementara keinginan manusia tidak terbatas (Istiqomah,2019:16). Baqir al-Sadr mengatakan bahwa puncak permasalahan ekonomi adalah bukan karena sumber daya yang tidak terbatas, akan tetapi karena ketamakan manusia yang tidak terbatas (Maulidizen, 2017: 52). Jika manusia bisa memanfaatkannya niscaya tidak akan pernah habis.

2. Mazhab Mainstream

Mazhab ini dipelopori oleh Muhammad abdul Mannan, Muhammad Nejatullah Siddiqi, syed Nawab Haidar Naqvi, dan Monzer Kahf. Pola utama pemikiran ini adalah kebalikan dari Mazhab Iqtishaduna. Dimana mereka sepakat bahwa masalah ekonomi muncul karena adanya keterbatasan sumber daya ekonomi. Keterbatasan ini tidak bisa untuk memenuhi kebutuhan manusia yang tidak terbatas. Mazhab mainstream ini memfokuskan pada cara mengelola sumber daya yang terbatas dan keinginan manusia yang tidak terbatas dengan tetap memberikan pandangan kritis terhadap aspek-aspek normative dalam ilmu ekonomi (Amarodin,2018: 52).

3. Mazhab Alternative Kritis 
Mazhab ini dipelopori oleh Prof. Timur Kuran, Jomo Kwame Sundaram, Muhammad Arif, dan lain-lain. Kelompok mazhab ini mengajak umat Islam untuk bersikap kritis tidak hanya terhadap kapitislme dan sosialisme, tetapi juga terhadap ekonomi islam. Mazhab alternative mengkritik pemikiran Baqir as-Sadr bahwa langkah mereka justru tidak konstruktif dan esendial. Ini karena mereka berusaha menemukan sesuatu yang baru yang seringkali sebenarnya sudah ditemukan oleh orang lain, membangun teori baru kemudian menghancurkan teori lama. Demikian pua mazhab Mainstream, menurut mereka, ia tidak lebih daripda pemikiran neoklasik dengan beranggapan modifikasi, seperti menghilangkan riba dan menambahkan zakat serta memperbaiki niat (Amarodin,2018: 53). Anggapan bahwa islam memang pasti benar, tetapi ekonomi islam belum tentu kebenarannya, karena merupakan hasil interpretasi manusia terhadap ajaran alqur'an dan hadist. Maka pernyataan di ekonomi islam perlu di uji kebenarannya sehingga dapat dibuktikan secara ilmiah (Istiqomah, 2019:16). 


\section{DAFTAR PUSTAKA}

Amarudin, M. (2018). Kontruksi Sistem Ekonomi Islam Pemikiran Tokoh Ekonomi Islam Kontemporer (Abu A'la al-Maududi, Baqir Ash-Sadr, dan Adiwarman Karim): Muchamat Amaruddin. EKSYAR:Jurnal Ekonomi Syari'ah \& Bisnis Islam, $5(01), 41-55$.

Havis Aravik, S. H. I. (2017). Sejarah Pemikiran Kontemporer Edisi Pertama. Kencana.

Istiqomah, L. (2019). Telaah Sejarah Pemikiran Ekonomi Islam. Al-iqtishod: Jurnal Ekonomi Syariah, 1(1), 1-19.

Janwari, Y. (2016). Jejak Langkah Sejarah Pemikiran Ekonomi Islam, Bandung: PT Remaja Rosdakarya.

Maulidizen, A. (2017). Pemikiran dan Kontribusi Tokoh Ekonomi Islam Klasik dan Kontemporer. Deliberatif, 1(1), 42-62.

Sirajuddin, S., \& Tamsir, T. (2019). Rekonstruksi Konseptual Kepemilikan Harta Perspektif Ekonomi Islam (Studi Kritis Kepemilikan Harta Sistem Ekonomi Kapitalisme), Laa Maisyir: Jurnal Ekonomi Islam, 6(2), 211-225. 